\title{
Effect of Total Solids on Biogas Production in a Fixed Dome Laboratory Digester under Mesophilic Temperature
}

\author{
Barasa H. Masinde ${ }^{1^{*}}$, Daudi M. Nyaanga ${ }^{2}$, Musa R. Njue ${ }^{2}$ and Joseph W. Matofari ${ }^{3}$ \\ ${ }^{1}$ Mechanical and Industrial Engineering Department, Masinde Muliro University of Science and Technology, P.O. \\ Box 190 - 50100, Kakamega, Kenya \\ ${ }^{2}$ Agricultural Engineering Department, Egerton University, P.O. Box 536 - 20115, Egerton, Kenya \\ ${ }^{3}$ Dairy, Food Science and Technology Department, Egerton University, P.O. Box 536 - 20115, Egerton, Kenya \\ Email: he.masb62@gmail.com
}

\begin{abstract}
An investigation on the effect of total solids on biogas production was done using a laboratory scale batch reactor of $0.15 \mathrm{~m}^{3}$ capacity. The feedstock was dung from dairy cows managed under a free-range system. Experiments were done on a substrate having total solids of $6 \%, 7 \%, 8 \%$, $9 \%$, and $10 \%$ at a constant temperature of $35^{\circ} \mathrm{C}$; and the mean biogas production was $0.249,0.304$, $0.487,0.287$, and $0.244 \mathrm{~m}^{3}$ of biogas per $\mathrm{m}^{3}$ of digester volume per day $\left(\mathrm{m}^{3} / \mathrm{m}^{3} \mathrm{~d}\right)$, respectively. It was concluded that the highest average biogas production of $0.487 \mathrm{~m}^{3} / \mathrm{m}^{3} \mathrm{~d}$ is attained at total solids of $8 \%$.
\end{abstract}

Keywords: total solids, biogas production, fixed dome, laboratory digester

\section{Introduction}

Biogas is an important form of renewable energy. It is stored in biological materials such as straw, manure and other agricultural products; and it is one of the key options for mitigating Green House Gas (GHG) emissions to replace fossil fuels [1, 2]. It can be used to generate heat, electricity, and produce transport fuel $[3,4]$. Each year, 590-880 million tonnes of methane are exhausted worldwide into the atmosphere through microbial activity and $90 \%$ of this comes from biogenic sources [5].

Anaerobic digestion is the process by which organic matter is broken down in the absence of oxygen to produce biogas, carbon dioxide and other traces of gases. The process of anaerobic digestion takes place through four successive stages: hydrolysis, acidogenesis, acetogenesis, and methanogenesis; and it is dependent on the interaction between diverse microorganisms that are able to carry out the four aforementioned stages [6]. In single stage batch reactors, the substrate is loaded and the four processes are allowed to occur in the same reactor sequentially; then the slurry is emptied after a predetermined retention time or the cessation of biogas production [6].

Working under the assumption that all the substrate is converted to $\mathrm{CH}_{4}$ and $\mathrm{CO}_{2}$, and that the carbon $(\mathrm{C})$, hydrogen $\left(\mathrm{H}_{2}\right)$ and oxygen $\left(\mathrm{O}_{2}\right)$ composition of the substrate are known, one can use the following equation and the general gas equation to find a theoretical molar and volumetric output of $\mathrm{CH}_{4}[7]$.

$$
\mathrm{C}_{n} \mathrm{H}_{a} \mathrm{O}_{b}+\left(n-\frac{a}{4}-\frac{b}{2}\right) \mathrm{H}_{2} \mathrm{O} \rightarrow\left(\frac{n}{2}-\frac{a}{8}+\frac{b}{4}\right) \mathrm{CO}_{2}+\left(\frac{n}{2}+\frac{a}{8}-\frac{b}{4}\right) \mathrm{CH}_{4}
$$

Under actual operating conditions, equation 1 was modified to account for the presence of ammonia $\left(\mathrm{NH}_{3}\right)$ and hydrogen sulphide $\left(\mathrm{H}_{2} \mathrm{~S}\right)$ in the waste as given in equation 2 below [8].

$$
\begin{aligned}
\mathrm{C}_{n} \mathrm{H}_{a} \mathrm{O}_{b} \mathrm{~N}_{x} S_{y}+ & \left(n-\frac{a}{4}-\frac{b}{2}+\frac{3 x}{4}+\frac{y}{2}\right) \mathrm{H}_{2} \mathrm{O} \\
& \rightarrow\left(n-\frac{a}{4}+\frac{b}{2}+\frac{3 x}{4}+\frac{y}{2}\right) \mathrm{CO}_{2}+\left(n+\frac{a}{4}-\frac{b}{2}-\frac{3 x}{4}-\frac{y}{2}\right) \mathrm{CH}_{4}+x \mathrm{NH}_{3}+y \mathrm{H}_{2} \mathrm{~S}
\end{aligned}
$$

Parameters that affect biogas production include substrate concentration, temperature, substrate retention time, carbon to nitrogen ratio, $\mathrm{pH}$, organic loading rate, nutrients, and toxicity [9]. The effects of these parameters are different on different microbial groups as each microbial group has different physiological and nutritional needs; and it is imbalances between them that cause instability [10]. An imbalance in the process caused due to the disturbance in the hydrolysis stage will limit the activities in the subsequent stages thereby reducing biogas production; a disturbance in methanogenesis will bring 
about an accumulation of acids that have been formed in previous stages; changes in the process such as reduced biogas production, accumulation of volatile fatty acids, decrease in $\mathrm{pH}$, and alkalinity are indicators of process instability [11]. In this study the effects of substrate concentration, temperature, and substrate retention time were investigated in a laboratory scale batch reactor.

There are three main temperature regimes for anaerobic digestion: psychrophilic $\left(<25^{\circ} \mathrm{C}\right)$, mesophilic $\left(30-40^{\circ} \mathrm{C}\right)$ and thermophilic $\left(50-70^{\circ} \mathrm{C}\right)[12]$. Mesophilic digestion operates in a lower temperature, is slower and yields less biogas. However, mesophilic digesters remain attractive because of their lower heater energy costs compared to thermophilic digesters [13]. The mesophilic range was used in this study. Thermophilic digestion, on the other hand, operates at a higher temperature with a consequent increase in reaction rates leading to increased biogas production $[14,15]$.

Substrate concentration can be determined in terms of volatile solids or total solids. Volatile solids content is determined by igniting the substrate at $550^{\circ} \mathrm{C}$ in the incinerator and then weighing the remaining contents [16]. Total solids is the measurement of dry matter as a percentage, and is determined by drying the sample at $103-105^{\circ} \mathrm{C}$ in succession until no further change in weight is observed $[16,17]$. Total solids were used in this study.

\section{Materials and Methods}

\subsection{Experiment Set-up and Material Preparation}

The influent was fed into the bioreactor from the feeding hopper through the inlet pipe until it rose to a level in the expansion chamber that closed the opening of the outlet pipe to minimize loss of biogas produced from the bioreactor during the anaerobic digestion process. The substrate was periodically stirred by the stirrer attached on the stirring rod with the help of an electric motor. Stirring was essential to break the scum, release the metabolites, and mix the substrate to acquire uniform distribution of temperature and bacteria. When gas was produced, it increased the pressure in the bioreactor and this forced the substrate to be displaced into the expansion chamber. To reduce the pressure, a gate valve was opened to allow the gas to escape through the gas delivery pipe. The gas ended up in an inverted graduated cylinder filled with water; and the water was displaced into the bucket.

Temperature was regulated by the water that surrounded the bioreactor. Water was heated by the electric immersion heaters in the hot water tank. Circulation of water was enabled by a centrifugal pump. A power supply provided electricity to the system for heating the water and monitoring the temperature through the power cable. A control unit has the instrumentation that allows water to be heated to a predetermined temperature only. A computer was attached to the control unit via a digital data logger. Thermocouple wires from the substrate in the bioreactor, water that surrounded the bioreactor, and the outside of the experiment set-up were connected to the data logger. The data was downloaded by the computer, and also real-time temperature was read on the screen of the computer. An insulation material was placed round the water to minimize heat loss.

Gas collection was by the water displacement method. A gas pipe was connected to an inverted graduated cylinder filled with water, and placed in a bucket of water. A gate valve was opened to allow the gas to displace water in the 500 millilitre capacity cylinder. This was done several times until the gas was exhausted for the duration of production. The volume of gas collected was then estimated for the production rate in cubic metres per cubic metre of digester volume per day $\left(\mathrm{m}^{3} / \mathrm{m}^{3} \mathrm{~d}\right)$ [18].

Biogas for analysis of methane content was collected in sampling bags and taken to a Gas Chromatograph (Acer Varian 3400CX model). The results were then analysed for percentage methane content in the sample.

\subsection{Total Solids}

Total solids are defined as a measure of dry matter left after the moisture has been removed from a moist sample. Dung from dairy cows, managed under a free-range system, was used as a substrate. Fresh cow dung was collected from Ngongogeri, an Egerton University farm, and taken to the laboratory for determining the total solids by percentage. At first, each can was cleaned and weighed while empty 
by using an electronic balance. Then every can was loaded with fresh dung, weighed, and then put in an air oven that was set at $105^{\circ} \mathrm{C}$ to heat the contents for 12 hours to attain a constant weight. Thereafter, each can and its content was removed and taken to a desiccator to cool down to room temperature. The desiccator has silica gel to ensure the hot dried dung does not re-absorb moisture from the atmosphere during the cooling process. After the dry samples attained room temperature, they were weighed again to determine their masses.

Three sets of experiments were done to take care of the variation in total solids content because of the change from the dry season to the wet season. Then an average value of total solids was used in subsequent calculations to prepare the influents.

Total solids (TS) was determined using the formula;

$$
T S=\left(\frac{c-a}{b-a}\right) \times 100
$$

where, $a=$ mass of dry can; $b=$ mass of dry can and fresh dung; $c=$ mass of dry can and dried dung.

Preparation of influent was done for every total solids value.

The influent was prepared based on the designed total solids percentage by diluting a predetermined amount of fresh cow dung with a calculated amount of clean water from the tap. The fresh cow dung had total solids of $18.6 \%$.

The effect of total solids on biogas production was investigated by running the experiment at $6 \%, 7 \%$, $8 \%, 9 \%$ and $10 \%$ for 18 days each. All the results were recorded and analyzed.

\subsection{Temperature Control}

The reactor was put in a water bath of warm water. Water was heated in a water tank using electric immersion heaters, and circulated by a centrifugal pump to ensure that the heated water releases heat to the reactor until the set temperature was achieved. The immersion heaters were regulated by a thermostat, which stopped the heating when the pre-set temperatures were attained. The temperature control was enabled by use of the partial differential integrals (PIDs) and program logic controls (PLCs).

In the control experiment, the same batch system was used. The substrate to water dilution was 1:1 as is usually done by biogas producers in Kenya [19]. The temperature was left at room conditions. Stirring the substrate was done for two minutes after every four hours [20]. The biogas production was recorded.

\section{Results and Discussions}

The results obtained at $35^{\circ} \mathrm{C}$ for various total solid levels were plotted as shown in figure 1 . There are three phases. In the first phase, there is no production of biogas from day 1 to day 5 for total solids of $7 \%$ and $8 \%$, from day 1 to day 6 for total solids of $6 \%$ and $9 \%$, and from day 1 to day 7 for total solids of $10 \%$. There is no biogas production from day 1 to day 5 . This is attributed to three processes of anaerobic digestion taking place: hydrolysis, acidogenesis and acetogensis. The first one is hydrolysis. Organic biomass contains complex polymers which are inaccessible to microorganisms without being further broken down through hydrolysis [21]. As a result, hydrolysis serves the purpose of rendering macromolecules into its smaller components which in turn can be utilized by acidogenic bacteria [12]. During hydrolysis, hydrolytic bacteria are able to secrete extracellular enzymes that can convert carbohydrates, lipids and proteins into simple sugars, long chain fatty acids and amino acids respectively $[22,23]$. After enzymatic cleavage, the products of hydrolysis are able to diffuse through the cell membranes of acidogenic microorganisms [24].

The second process is acidogenesis. Acidogenic bacteria are able to produce intermediate volatile fatty acids (VFAs) and other products [12]. VFAs constitute a class of organic acids such as acetates, and larger organic acids such as propionate and butyrate [25]. As opposed to other stages, acidogenesis is generally believed to proceed at a faster rate than all other processes of anaerobic digestion, with acidogenic bacteria having a regeneration time fewer than 36 hours [26]. With the rapidity of this stage, the production of volatile fatty acids creates direct precursors for the final stage of methanogenesis; VFA acidification is widely reported to be a cause of digester failure [27]. 


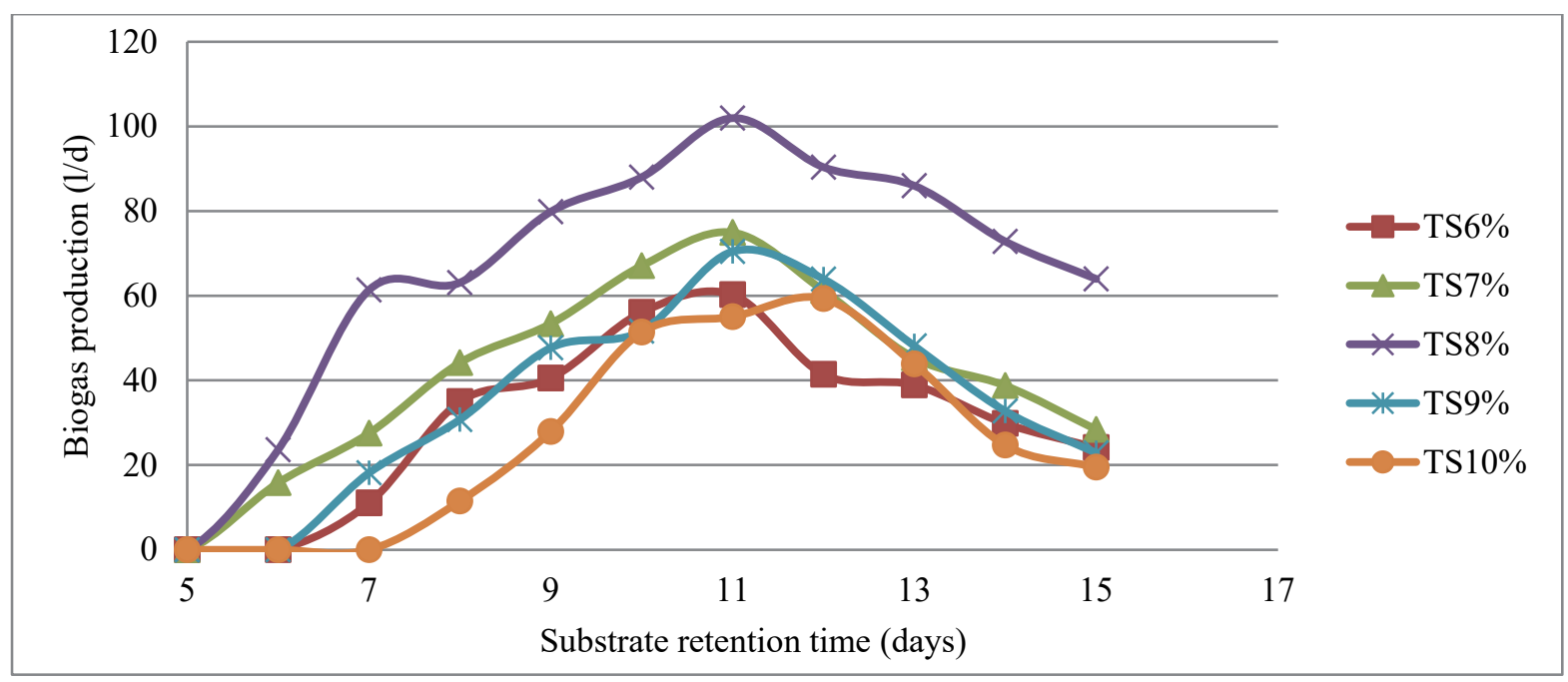

Figure 1. Biogas production trends for various total solid levels

Acetogenesis is the third process during which higher volatile fatty acids (e.g. propionate and butyrate) are converted into acetate and hydrogen [28]. At the same time, lipids undergo a separate pathway of acetogenesis through acidogenesis and $\beta$-oxidation, where acidogenesis produces acetate from glycerol, while $\beta$-oxidation produces acetate from LCFAs [29].

Biogas production is very slow at the beginning due to the lag phase of microbial growth [30]. The biogas production in batch condition is directly proportional to the specific growth rate of methanogenic bacteria in the bioreactor [31]. Hydrolysis takes 2 days while acidogenesis and acetogenesis take 3.6 days [32].

In the second phase there is an exponential production of biogas from day 5 up to day 11 and day 12 . Methanogenesis marks the final stage of anaerobic digestion, where accessible intermediates are consumed by methanogenic bacteria to produce methane [33]. Production of biogas starts from day 5 and increases steadily to day $11(102.00 \mathrm{l} / \mathrm{d})$. Methanogenic bacteria are confined to a small selection of substrates [12]. Aceticlastic methanogenesis from acetate accounts for nearly two thirds of the methane production while the remaining one third comes from hydrogenotrophic methanogenesis $[34,35]$. This can be summarized by the following equations:

i. Hydrogenotrophic methanogenesis

ii. Aceticlastic methanogenesis

$$
4 \mathrm{H}_{2}+\mathrm{CO}_{2} \rightarrow \mathrm{CH}_{4}+2 \mathrm{H}_{2} \mathrm{O}
$$

$$
\mathrm{CH}_{3} \mathrm{COOH} \rightarrow \mathrm{CH}_{4}+\mathrm{CO}_{2}
$$

It was noticed, however, that biogas production stagnated from day 7 to day 8 , and day 8 to 9 for $8 \%$ and $6 \% \mathrm{TS}$, respectively. This was attributed to excessive partial pressure of hydrogen produced by acetogenesis that deleted acetogenic microorganisms [36]. But due to the presence of hydrogenotrophic methanogens, especially the methanosarcina species, hydrogen was able to be rapidly consumed while maintaining partial pressure at a level favourable to acetogenesis by creating an exergonic reaction [37]. During the stagnation period, methanosarcina species, which tend to be robust and are capable of withstanding ammonia, sodium, and acetate concentrations in addition to $\mathrm{pH}$ shocks at levels that would otherwise be detrimental to other methanogenic bacteria, kept on producing biogas [38]. Consequently the steady production of biogas was restored.

Methanogenic bacteria represent a group of obligate anaerobic archaea; as an acute sensitivity, it was found that $99 \%$ of methanococcus voltae and methanococcus vannielli cells had been killed within ten hours upon exposure to oxygen [39]. Methanogens have a slower regeneration time than other bacteria in an anaerobic digestion; at least 5 to 16 days [26]. However, some hydrogenotrophic species, such as methanococcus maripaludis, have a doubling time of only two hours [40].

In the third phase there is a steady decline in biogas production from day 11 to day 15 . This is due to stationary phase of microbial growth caused by the depletion of nutrients in the substrate and the 
gradual death of the methanogens [41]. In batch reactors, the end of methanogenesis is determined when biogas production stops, which can take about 40 days [6].

Figure 2 shows the average biogas production rate values for different TS contents. The rates are $37.46,45.67,73.12,42.94$, and $36.66 \mathrm{l} / \mathrm{d}$ for $6,7,8,9$, and $10 \%$ TS, respectively.

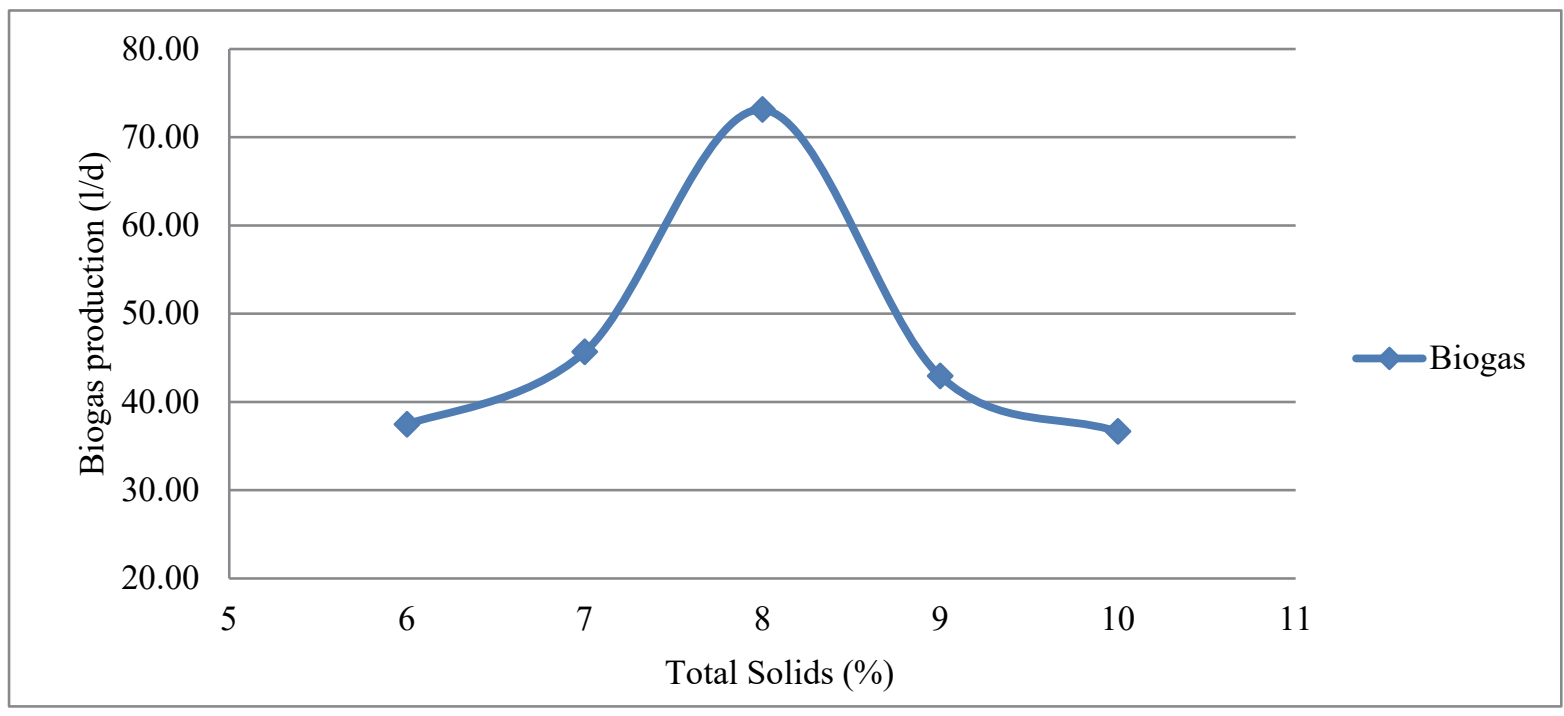

Figure 2. Average biogas production for various total solid levels

Anaerobic digestion process is stable from total solids of $6 \%$ to $8 \%$. At low solids, aceticlastic methanogens called methanosarcina play an important role, followed by hydrogenotrophic methanoculleus and methanomicrobiales species [42]. Methanosarcina, a typical member of aceticlastic methanogens, have often been reported to be dorminant methanogens in anaerobic digestion [43]. The ability of genus methanosarcina having high growth rates and forming irregular cell clumps makes them more tolerant to changing $\mathrm{pH}$ and high concentrations of toxic ionic agents [44]. Methanosarcina produce methane from acetate (although some species are more versatile and can also utilize hydrogen and carbon dioxide), methylated amines and methanol, and also use both the aceticlastic and hydrogenotrophic methanogenesis pathways compared to methanosaeta species [38].

As the total solids increases from $8 \%$ to $10 \%$, the biogas production declines steadily. Increasing the total solids means a higher applied organic loading rate and more volatile solids for microorganisms which results in higher volatile fatty acid concentrations [42], and this favours the growth of methanosarcina species [38]. On the other hand, methanoculleus species population declines in mesophilic anaerobic digesters with an increase in total solids content [45]. The changing of microbial communities in mesophilic anaerobic digestion of cow dung was responsible for the performance exhibited in figure 3 .

This observation is similar to the work reported by Igoni, Abowei, Ayotamuno and Eze [46] on a batch reactor. A marginal increase in the percentage of total solids results in a geometric increase in the volume of biogas produced, suggesting therefore (as seen in Figure 3) that a continual increase in the percentage of total solids at some point becomes immaterial to the increasing volume of biogas produced. This is possible because when percentage of total solids increases, the amount of water decreases, thus reducing the level of microbial activity, which then affects the amount of biogas, particularly at higher values of the TS\% [46].

Itodo and Awulu [47] showed that slurries of higher total solids concentrations were more acidic than that of lower total solids concentrations, which is an additional reason why higher total solids values would not significantly affect the increasing volume of biogas produced. Abbassi-Guendouz, Brockmann, Trably, Dumas and Delgenès [48] showed that the total methane production decreased with total solids contents increasing from $10 \%$ to $25 \%$ in batch anaerobic digestion of cardboard under mesophilic conditions. Forster-Carneiro, Pérez and Romero [49] also showed that the biogas and methane production decreased with total solids contents increasing from $20 \%$ to $30 \%$ in dry batch anaerobic 
digestion of food waste. It can be deduced from the graphs that generally at low concentrations of total solids, the gas production increases steadily than at higher concentrations of total solids [50-52]. It can also be noticed that as the solid concentration increases above $8 \%$, the gas production begins to drop or falls drastically [53].

\section{Conclusion}

Biogas production increased from $6 \%$ TS to reach a maximum average of $73.12 \mathrm{l} / \mathrm{d}$ (or $0.48 \mathrm{~m}^{3} / \mathrm{m}^{3} \mathrm{~d}$ ) at $8 \%$ total solids (or a substrate to water ratio of 1:1.3), and then started decreasing steadily as the total solids increased.

Acknowledgment. The project was funded by the National Council for Science, Technology, and Innovation (Nacosti). We are also grateful to Egerton University for hosting the project.

\section{References}

1. Sovacool B.K. The political economy of energy poverty: A review of key challenges. Energy for Sustainable Development, 2012, 16 (3):272-282.

2. Elaiyaraju P., Partha N. Studies on biogas production by anaerobic process using agroindustrial wastes. Research in Agricultural Engineering, 2016, 62 (2):73-82.

3. Taherzadeh M., Karimi K. Pretreatment of lignocellulosic wastes to improve ethanol and biogas production: a review. International journal of molecular sciences, 2008, 9 (9):1621-1651.

4. Tricase C., Lombardi M. State of the art and prospects of Italian biogas production from animal sewage: technical-economic considerations. Renewable Energy, 2009, 34 (3):477-485.

5. Charlton S., Dollmeyer T., Grana T. Meeting the US heavy-duty EPA 2010 standards and providing increased value for the customer. SAE International Journal of Commercial Vehicles, 2010, 3 (2010-01-1934):101-110.

6. Verma S. Anaerobic Digestion of Biodegradable Organics in Municipal Solid Wastes. 2002.

7. Buswell A., Mueller H. Mechanism of methane fermentation. Industrial and Engineering Chemistry, 1952, 44 (3):550-552.

8. Achinas S., Euverink G.J.W. Theoretical analysis of biogas potential prediction from agricultural waste. Resource-Efficient Technologies, 2016, 2 (3):143-147.

9. Parawira W., Murto M., Read J., Mattiasson B., Profile of Hydrolyses and Biogas., 2005.

10. Dolud M., Andree H., Hügle T. Rapid analysis of liquid hog manure using near-infrared spectroscopy in flowing condition. Precision livestock farming '05. Wageningen Acad. Publ., Wageningen, the Netherlands, 2005, 115122.

11. Barnes R., Dhanoa M.S., Lister S.J. Standard normal variate transformation and de-trending of near-infrared diffuse reflectance spectra. Applied spectroscopy, 1989, 43 (5):772-777.

12. Meegoda J., Li B., Patel K., Wang L. A review of the processes, parameters, and optimization of anaerobic digestion. International Journal of Environmental Research and Public Health, 2018, 15 (10):2224.

13. Moset V., Poulsen M., Wahid R., Højberg O., Møller H.B. Mesophilic versus thermophilic anaerobic digestion of cattle manure: methane productivity and microbial ecology. Microbial biotechnology, 2015, 8 (5):787-800.

14. Lettinga G., Field J., Van Lier J., Zeeman G., Pol L.H. Advanced anaerobic wastewater treatment in the near future. Water Science and Technology, 1997, 35 (10):5-12.

15. Franke-Whittle I.H., Walter A., Ebner C., Insam H. Investigation into the effect of high concentrations of volatile fatty acids in anaerobic digestion on methanogenic communities. Waste Management, 2014, 34 (11):2080-2089.

16. EPA. Method 1684: Total, Fixed, and Volatile Solids in Water, Solids, and Biosolids. U.S. Environmental Protection Agency, 2001.

17. APHA. Standard Methods for the Examination of Water and Wastewater. American Public Health Association, 1999.

18. Mudhoo A., Moorateeah P., Mohee R. Effects of microwave heating on biogas production, chemical oxygen demand, and volatile solids solubilization of food residues. World Academy of Science, Engineering and Technology, 2012, 69 . 
19. Nyaanga D., Performance of Tropical Biogas, Egerton University International ConferenceEgerton University, Kenya, 2011.

20. Lemmer A., Naegele H.-J., Sondermann J. How Efficient are Agitators in Biogas Digesters? Determination of the Efficiency of Submersible Motor Mixers and Incline Agitators by Measuring Nutrient Distribution in FullScale Agricultural Biogas Digesters. Energies, 2013, (6):6255-6273.

21. Gujer W., Zehnder A. Conversion processes in anaerobic digestion. Water Science and Technology, 1983, 15 127167.

22. Li Y., Park S., Zhu J. Solid-state anaerobic digestion for methane production from organic waste. Renew. Sustain. Energy Rev, 2011, 15 821-826.

23. Pavlostathis S., Giraldo-Gomez E. Kinetics of anaerobic treatment: a critical review. Critical Reviews in Environmental Science and Technology, 1991, 21 (5-6):411-490.

24. van Lier J., Mahmoud N., Zeeman G. Anaerobic Wastewater Treatment. In Biological Wastewater Treatment: Principles, Modelling and Design. International Water Association, UK, 2008, 401-442.

25. Bergman H., Wichmann T., DeLong M.R. Reversal of experimental parkinsonism by lesions of the subthalamic nucleus. Science, 1990, 249 (4975):1436-1438.

26. Deublein D., Steinhauser A. Biogas from Waste and Renewable Resources: An Introduction. John Wiley and Sons: Hoboken, NJ, USA, 2008.

27. Akuzawa M., Hori T., Haruta S., Ueno Y., Ishii M., Igarashi Y. Distinctive responses of metabolically active microbiota to acidification in a thermophilic anaerobic digester. Microbial ecology, 2011, 61 (3):595-605.

28. Hansen C., Cheong D., Agricultural Waste Management in Food Processing, Academic Press, Cambridge, MA, USA, 2013.

29. Cirne D., Paloumet X., Björnsson L., Alves M., Mattiasson B. Anaerobic digestion of lipid-rich waste-Effects of lipid concentration. Renew. Energy, 2007, 32 965-975.

30. Budiyono, Widiasa I., Johari S., Sunarso. The influence of total solid contents on biogas yield from cattle manure using rumen fluid inoculum. Energy Research Journal, 2010, 1 (1):6-11.

31. Nopharatana A., Pullammanappallil P.C., Clarke W.P. Kinetics and dynamic modelling of batch anaerobic digestion of municipal solid waste in a stirred reactor. Waste management, 2007, 27 (5):595-603.

32. Varma R., Vesvikar M., Karim K., Hoffman R., De Paoli D., Klasson K., Winterberg A., Alexander C., Bioenergy production from anaerobic digestion of animal and farm wastes, Energy summitMissouri University of Science and Technology, 2009.

33. Ferry J. The chemical biology of methanogenesis. Planet. Space Sci, 2010, 58 1775-1783.

34. Belay N., Sparling R., Daniels L. Relationship of formate to growth and methanogenesis by Methanococcus thermolithotrophicus. Appl. Environ. Microbiol., 1986, 52 (5):1080-1085.

35. Lovley D., Klug M. Methanogenesis from Methanol and Methylamines and Acetogenesis from Hydrogen and Carbon Dioxide in the Sediments of a Eutrophic Lake. Appl. Environ. Microbiol., 1983, 45 1310-1315.

36. Dinopoulou G., Rudd T., Lester J. Anaerobic acidogenesis of a complex wastewater: The influence of operational parameters on reactor performance. Biotechnol. Bioeng, 1988, 31 958-968.

37. Stams A., Plugge C. Electron transfer in syntrophic communities of anaerobic bacteria and archaea. Nat. Rev. Microbiol, 2009, 7 568-577.

38. De Vrieze J., Hennebel T., Boon N., Verstraete W. Methanosarcina: The rediscovered methanogen for heavy duty biomethanation. Bioresour. Technol, 2012, 112 1-9.

39. Kiener A., Leisinger T. Oxygen sensitivity of methanogenic bacteria. Syst. Appl. Microbiol, 1983, 4 305-312.

40. Richards M., Lie T., Zhang J., Ragsdale S., Leigh J., Price N. Exploring hydrogenotrophic methanogenesis: A genome scale metabolic reconstruction of methanococcus maripaludis. J. Bacteriol, 2016, 198 3379-3390.

41. Castillo R.-T., Luengo P., Alvarez J.M. Temperature effect on anaerobic of bedding manure in a one phase system at different inoculums concentration. Agriculture, Ecosystems and Environment, 1995, 54 55-66.

42. Yi J., Dong B., Jin J., Dai X. Effect of Increasing Total Solids Contents on Anaerobic Digestion of Food Waste under Mesophilic Conditions: Performance and Microbial Characteristics Analysis. PMCID: PMC4106828, 2014, $9(7)$.

43. Demirel B., Scherer P. The roles of acetotrophic and hydrogenotrophic methanogens during anaerobic conversion of biomass to methane: a review. Rev Environ Sci Biotechnol 2008, (7):173-190.

44. Conklin A., Stensel H., Ferguson J. Growth kinetics and competition between Methanosarcina and Methanosaeta in mesophilic anaerobic digestion Water Environ Res, 2006, (78):486-496.

45. Bourque J., Guiot S., Tartakovsky B. Methane production in an UASB reactor operated under periodic mesophilic-thermohilic conditions. Biotechnol Bioeng, 2008, (100):1115-1121. 
46. Igoni A.H., Abowei M., Ayotamuno M., Eze C. Effect of total solids concentration of municipal solid waste on the biogas produced in an anaerobic continuous digester. Agricultural Engineering International: CIGR Journal, 2008.

47. Itodo I., Awulu J. Effects of total solids concentrations of poultry, cattle, and piggery waste slurries on biogas yield. Transactions of the ASAE 1999, 42 (6):1853-1855.

48. Abbassi-Guendouz A., Brockmann D., Trably E., Dumas C., Delgenès J. Total solids content drives high solid anaerobic digestion via mass transfer limitation. Bioresour Technol 2012, 111 55-61.

49. Forster-Carneiro T., Pérez M., Romero L. Influence of total solid and inoculum contents on performance of anaerobic reactors treating food waste Bioresour Technol, 2008, (99):6994-7002.

50. Beevi B.S., Madhu G., Sahoo D.K. Performance and kinetic study of semi-dry thermophilic anaerobic digestion of organic fraction of municipal solid waste. Waste management, 2015, 36 93-97.

51. Tsunatu D., Azuaga I., Agabison J. Evaluation of the effect of total solids concentration on biogas yields of agricultural wastes. International Research Journal of Environment Sciences, 2014, 3 (2).

52. Liu Z., Jian L. The effect of total solids concentration and temperature on biogas production by anaerobic digestion. Energy sources, Part A: Recovery, utilization, and environmental effects, 2016, 38 (23):3534-3541.

53. Eltawil M., Belal E. Evaluation and scrubbing of biogas generation from agricultural wastes and water hyacinth biological engineering. Misr Journal Ag. Eng, 2009, 26 (1):534-560. 